\title{
Investigation of the effects of different disinfectant solutions on honey bees (Apis mellifera)
}

\author{
Sedat SEVIN ${ }^{1, a^{*}}$, Ahmet CEYLAN ${ }^{2, a}$, Ö̈ge ÖZGENÇ ${ }^{2, c}$, Gökhan AKDENİZ ${ }^{3, d}$, Fatih YILMAZ ${ }^{3, e}$, \\ Dilek KABAKÇII ${ }^{4, f}$, Ender YARSAN ${ }^{1, g}$
}

${ }^{1}$ Ankara University, Faculty of Veterinary Medicine,Department of Pharmacology and Toxicology, 06110, Ankara, Turkey

${ }^{2}$ Ankara University, Faculty of Veterinary Medicine Department of Histology and Embryology, 06110, Ankara, Turkey

${ }^{3}$ Republic Of Turkey Ministry Of Agriculture And Forestry, Apiculture Research Institute, Dedeli, 52200, Ordu, Turkey

${ }^{4}$ Mus Alparslan University, Faculty of Applied Sciences Department of Animal Production and, 49250, Muş, Turkey

ORCID: 0000-0003-0475-9092 ${ }^{a}$; 0000-0001-5878-8775 ${ }^{b}$; 0000-0002-8776-4788 ${ }^{c}$; 0000-0003-1493-3832 ${ }^{d}$; 0000-0002-6069-7335 ${ }^{e}$;

0000-0002-3296-0394f ; 0000-0002-3008-9240g

\begin{abstract}
MAKALE BILGISI/
ARTICLE

INFORMATION:

Geliş / Received:

4 Ocak 2021

4 January 2021
\end{abstract}

Revizyon / Revised:

26 Mart 2021

26 March 2021

Kabul / Accepted:

16 Nisan 2021

16 April 2021

Anahtar Sözcükler:

Ar1 sağlı̆̆ 1

Bal arıs1

Biyosidal

Dezenfektan

Nano gümüş

Keywords:

Bee health

Biocidal

Disinfectant

Honey bee

Nano silver

\section{ABSTRACT:}

In this study, it was aimed to investigate the toxic effects of biocidal and nano silver-containing disinfectants, which were used in beekeeping, on bees. Biocidal and nano-silver-containing preparations used in disinfection of hives were obtained from commercial companies. Syrup (1/1 sucrose-water) was given to the control group (Group $1 ; \mathrm{n}=10)$. Biocidal preparation (Group 2; $\mathrm{n}=10$ ) and nano-silver containing preparation (Group 3;n=10) were given to one of the experimental groups via an automatic pipette, orally $2 \mu \mathrm{l}$ per bee. 24 hours after the application, the bees that died in all groups were counted and the midgut tissues of the bees that survived in the groups were taken for histomorphological analysis. No application was performed in the control group (Group 1). Different disinfection solution was used in the group 2 (biocidal ingredient) and Group 3 (nano silver contents). The preparations were applied to the groups by spraying and bee deaths were recorded. Two disinfectants applied to the hives under field conditions, were found to cause more bee deaths than the control group. The highest bee death was in the nano silver group. In laboratory trials, the nano-silvercontaining preparation was observed to cause high number of bee deaths and serious damage to the midgut epithelium in histomorphological examinations. The results of the study showed that direct application of disinfectant substances on bees caused serious deaths in the colony. Biocidal and chemical based preparations and hive disinfection should be applied in the empty beehives.

\section{Farklı dezenfektan solüsyonlarının bal arıları (Apis mellifera) üzerindeki etkilerinin araştırilmast}

ÖZET:

$\mathrm{Bu}$ çalışmada arıcılıkta kullanılan biyosidal ve nano gümüş içerikli dezenfektanların arılar üzerine toksik etkilerinin araştırılması amaçlanmıștır. Kovanların dezenfeksiyonunda kullanılan biyosidal içerikli ve nano gümüş içerikli preparatlar ticari firmalardan temin edildi. In vivo denemeler için 3 grup oluşturuldu. Kontrol grubuna (Grup $1 ; n=10$ ) sadece şurup ( $1 / 1$ oranında sakkaroz-su) verildi. Deneme gruplarından birine biyosidal içerikli preparat (Grup $2 ; n=10)$ ve diğerine nano gümüş içerikli preparat (Grup 3; n=10) oral yolla arı başına $2 \mu 1$ olacak şekilde otomatik pipet ile verildi. Uygulamadan 24 saat sonra tüm gruplarda ölen arılar sayıldı ve histomorfolojik analizler için gruplarda canlı kalan arıların mideleri alındı. Saha denemeleri Ordu Arıcılık Enstitüsü Müdürlüğü arılığında gerçekleştirildi. Herhangi bir uygulama yapılmayan kontrol grubu (Grup 1) ile birlikte biyosidal içerikli (Grup 2) ve nano gümüş içerikli (Grup 3) preparatların uygulandığı iki uygulama grubu oluşturuldu. Preparatlar gruplara püskütme şeklinde uygulandı ve arı ölümleri kaydedildi. Saha koşullarında kovanlara uygulanan iki dezenfektan, kontrol grubuna göre daha çok arı ölümlerine sebep oldu. En fazla arı ölümleri Nano gümüş içerikli dezenfektanın uygulandığı kovanlarda görüldü. Laboratuar denemelerinde nano gümüş içerikli preparatın yüksek oranda arı ölümlerine ve histomorfolojik incelemelerde mide epitelinde ciddi hasarlara neden olduğu belirlendi. Çalışma sonuçları, dezenfektan maddelerin arılar üzerine doğrudan uygulanmasının kolonide ciddi ölümlere neden olduğunu göstermiştir. Biyosidal ve kimyasal tabanlı preparatlar ile yapılacak kovan dezenfeksiyonu, arıların bulunmadığı dönemde gerçekleştirilmelidir.

How to cite this article: Sevin S, Ceylan A, Özgenç Ö, Akdeniz G, Yılmaz F, Kabakçı D, Yarsan E: Investigation of the effects of different disinfectant solutions on honey bees (Apis mellifera). Veteriner Hekimler Dernegi Dergisi, 92(2): 143-151, 2021, DOI: 10.33188/vetheder.852336 


\section{Introduction}

Bees are extremely important to humanity. In addition to the production of honey and other bee products, honey bee (Apis mellifera L) is the world's most important pollinator type in natural ecosystems and therefore they contribute significantly to the natural ecosystems. Honey bees enable plants to reproduce and contribute to food safety which is indispensable for the conservation of biological diversity. Honey bees allow plants to reproduce and contribute to food safety that is required for the conservation of the biological diversity $(1,2,3)$. The pollinator crisis threatens global and local food security, which leads to increase hunger problems, erodes ecosystem resistance and causes the ecosystems that make the support system worse (4).

Turkey takes the lead in terms of having about 8 million colonies per barrel, however, it remains below the world average with $15 \mathrm{~kg}$ of honey production (5). Our country has an extremely advantageous position for beekeeping as it has 12,000 species of plants, which 3000 of them are endemic (6). Although the number of colonies and honey production increases year by year, there is a decrease in productivity (5). Turkey cannot reach its optimum honey production levels due to a variety of different reasons (7). The most important underlying reason behind this is due to honey bee diseases and pests. Bee diseases might be classified as bacterial (American and European Foulbrood Septicemia), fungal (Lime and Stone disease), viral (Bee Paralysis), parasitic (Varroa destructor, Acarapis woodi) and protozoon (Nosema and Amoeba). Also, it might be classified as an adult and juvenile bee disease according to the hosts that they are stemmed (8). Fighting methods of Bee diseases consist of physical, biological and chemical methods. However, the complete elimination of the disease or parasite is not possible with the currently available methods. The use of chemicals carries great importance in the fight against bee diseases. Up to now, misusage of effective chemical drugs in fight against varroa caused resistance against these chemicals and these chemicals leave residues in bee products $(9,10)$.

Previous research shows that bee health is threatened by various pathogens $(11,12)$. Colony management in beekeeping can greatly affect the vitality and health of bees, but also plays an important role in spread and control of disease. Bee diseases were found higher in the ones that are grown in common hives (13). In addition to the damage caused by the chemicals used in the treatment of bee diseases and pests, these chemicals also have negative effects on bees and other species in nature. For this reason, organic materials with less harmful effects should be used in terms of bee health (10). Recently, preventive medicine comes to the forefront due to the resistance related concerns (14).

Disinfection is a method that is used to stop or destroy the reproduction of microorganisms on living or nonliving materials in microorganisms. It is generally used to prevent infections that might occur after microbial contamination $(15,16)$. Some disinfection materials are also used to prevent contamination of various microorganisms, including bacteria, fungi, viruses, protozoa and parasites in the hives (17). Hydroxides $(\mathrm{KOH}, \mathrm{NaOH}, \mathrm{Ca}(\mathrm{OH}) 2$ and alkaline salts, sodium carbonate, inorganic (mineral) acids, organic acids, oxidizing agents, halogens, metals and compounds, aldehydes, alcohols and ethers are also used in chemical disinfectants $(16,18)$.

Dağlığlu et al (19) investigated the effect of metal and metal oxide nanoparticles on bees (Apis mellifera) for 48 and 96 hours by using PVF + (Polyvinyl ferrocene) K2PdCl4 and Pt / PVF + nanoparticles. They found that the LC50 dose for all those three materials was decreased by exposure time. They also noted that the toxic effect increased due to the duration of exposure. In another study, Dağlioğlu et al (20) compared the acute toxicity of nano-boron and non-nano-boron particles on Apis mellifera, they calculated LC50 values for 0.001, 0.01, 0.1 and $1 \mathrm{mg}$ concentration of nano and non- boron particles at 48 and 96 hours. These values were $229.0 \mathrm{mg} / \mathrm{L}, 0.339 \mathrm{mg} / \mathrm{L}$ and $62.3 \mathrm{mg} / \mathrm{L}, 4.6$ $\mathrm{mg} / \mathrm{L}$ respectively. They found that nano boron was found toxic at 96 hours.

Özkan et al (21) found that the toxic effects of $\mathrm{TiO} 2, \mathrm{ZnO}-\mathrm{TiO} 2$ and $\mathrm{Ag}-\mathrm{TiO} 2$ nanoparticles increase by the concentration and duration of exposure. LC50 values for 96 hours were calculated as $5.865 \mathrm{mgL}-1$ for TiO2, 6.315 mgL-1 for $\mathrm{ZnO}-\mathrm{TiO} 2$ and $312.845 \mathrm{mgL}-1$ for Ag-TiO2.

Another chemical disinfection used that is used in bee hive coating was nano-silver. It is found that protection of fungi and bacteria can be ensured by covering the hives with nano-silver (22). Physical disinfection methods are generally more environmentally friendly than the chemical methods. They are based on the use of heat and radiation in dry or wet condition. These physical methods are burning, applying Ultraviolet (UV) Radiation, hot water disinfection, 
hot air disinfection, pasteurization $\left(85-90^{\circ} \mathrm{C}\right)$, steam disinfection $(16)$.

Disinfection of the hives and the used equipment in beekeeping are very important in preventing the diseases. Disinfectants action spectrum, their toxic on target and off-target organisms should be investigated. However, there need to be more research about the optimum dose for beekeeping disinfectants, their toxic effects on bees and the determination of residual levels in bee products. The aim of this study is to investigate the toxic effects of two different disinfection preparates that are used as disinfection of bee equipment in our country.

\section{Material and Methods}

\section{Chemicals and equipment:}

In the studies, the bees of the Black Sea ecotype (Apis mellifera L.) obtained from the province of Ordu Apiculture Research Institute were used. Biocidal content and nano silver content preparates which were used in disinfection of hives and beekeeping materials were obtained from the commercial company. Cages ( $70 \mathrm{~mm} \times 80 \mathrm{~mm}$ $\mathrm{x} 120 \mathrm{~mm}$ ) that will be used for in-vitro trials were specially made. Bees, which will be used in cage experiments, were obtained from Sedat Sevin's honey bee apiary in Kahramankazan district of Ankara province of Turkey. The cages were kept in a thermostatically controlled environment with the temperature of $32{ }^{\circ} \mathrm{C}$ and humidity at $55 \%$. The hives to be used in field studies were obtained from Ordu Apiculture Institute. For histomorphological examinations, microsurgery set, slide, coverslip, chemical dyes and stereomicroscope, glass jars with different volumes, micropipette, freezer, vortex mixer, centrifuge were used for plant extraction. In vitro trials, Syrup (1/1 sucrose-water) was used for bee feeding.

\section{Preparation of experimental groups and implementation:}

In vivo trials: Suitable living conditions for bees were provided by using air-conditioning cabinets. Honey bees were kept for 3 days to adapt to the environment before the experiments. The bees were fasted for 1-2 hours before starting the application. Application was made considering the maximum daily water consumption volume of bees (0.047 ml per bee) (23). Three groups were formed, one for the control and two for the trial group. Syrup was given to the control group (Group 1, $\mathrm{n}=10$ ). Biocidal preparation (Group 2, $\mathrm{n}=10$ ) was given to one of the experimental groups and the preparation with a nano-silver content (Group 3, $\mathrm{n}=10$ ) was given orally, with an automatic pipette of $2 \mu \mathrm{l}$ per bee. 3 repetitions were done in each group. 24 hours after the application, the bees that died in all groups were counted and the midgut and hindgut tissues of the bees that survived in the groups were taken for histomorphological analysis.

\section{Field Trials:}

Field trials were done in the apiary of Ordu Apiculture Institute. Three trial groups were applied, the first control (Group 1, the group without any application), the second with biocidal preparation (Group 2) and the third with nano-silver-containing preparation (Group 3). While the bees were in the hive, two commercial preparations were applied by spraying them into the hives. Zero (never used), Langstroth type beehives were first disinfected with disinfectant materials in a level that a total wetness would occur, and the trials were set by transferring the bees to the homogeneous seven-framed beehives having same-aged sister queen bees. No additional feeding was made to the bees during the trial and on the following days. The bees thrown in the cloth, which were laid in front of the hive at the same hours on the 1 st day and the 2nd day, were counted and deaths were determined. Bee deaths were determined in 24 hours and 48 hours following the application.

\section{Histomorphological analysis:}

To expose the midgut and hindgut the thorax and last abdomen parts were pulled in opposite directions with the help of sterile forceps. All samples were fixed in $10 \%$ neutral buffered formalin for 24 hours. Then, samples were passed through graded alcohols and xylol respectively and embedded in paraplast. Crossmon's trichrome staining was 
performed on sections of $5 \mu \mathrm{m}$ thickness in order to reveal the morphological structure. For the microscopic analysis, the slides were examined and photographed (Leica DFC450) using a Leica DM 2500 light microscope (24).

\section{Statistical analysis:}

Before proceeding with statistical analysis, the appropriateness of the data to normal distribution was evaluated with the Shapiro Wilk Test. Data were summarized as mean \pm standard deviation. Change in the number of dead bees on consecutive days, the statistical importance of this change in the control group, Nano-silver and biocidal groups were analyzed with Repeated Measures ANOVA. The viability status of bees and the statistical difference between the groups, after being evaluated with the Chi-Square Test, Bonferroni method was put into use in the correction of $p$ values in further analysis to determine the difference between the groups. Statistical limit of significance was accepted as $\mathrm{P}<0.05$. SPSS 14.01 package program was used in all statistical analyses.

\section{Results}

In field trials, higher number of bee deaths were observed in the experimental groups compared to the control group (Table 1). When the effect of the groups was ignored, it was determined that there was a statistically significant increase in the average number of dead bees observed on the 2 nd day compared to the 1 st day $(\mathrm{P}=0.014)$. When the change in the average number of dead bees from the first day to the 2nd day was examined, it was determined that this change did not create a statistically significant difference between the groups $(\mathrm{P}=0.166)$. When the effect of time (days) was ignored, it was determined that there was no statistically significant difference between groups in terms of average number of dead bees $(\mathrm{P}=0.187)$ (Table 2).

Table 1: Bee deaths observed in the first two days in field trials

Tablo 1: Saha denemelerinde ilk iki günde gözlemlenen arı ölümleri

\begin{tabular}{|c|c|c|c|c|c|c|c|c|c|c|c|c|c|c|c|}
\hline Group & & & rou & & & & & coup & & & & & roul & & \\
\hline Hive & 1 & 2 & 3 & 4 & 5 & 1 & 2 & 3 & 4 & 5 & 1 & 2 & 3 & 4 & 5 \\
\hline $\begin{array}{l}\text { 24th } \\
\text { hour }\end{array}$ & 4 & 10 & 10 & 11 & 15 & 24 & 7 & 19 & 30 & 31 & 12 & 11 & 30 & 25 & 21 \\
\hline $\begin{array}{l}\text { 48th } \\
\text { hour }\end{array}$ & 10 & 21 & 20 & 20 & 21 & 13 & 14 & 14 & 41 & 29 & 19 & 28 & 16 & 25 & 20 \\
\hline
\end{tabular}

Table 2: The differences among the groups of bee deaths in field trials

Tablo 2: Saha denemelerinde arı ölümlerinin gruplar arasındaki farklılıkları

\begin{tabular}{|c|c|c|c|c|c|c|}
\hline & & \multicolumn{2}{|c|}{ Number of dead bees } & \multicolumn{3}{|c|}{$\mathbf{P}$} \\
\hline & & 1th day & 2th day & Day & Day *Group & Group \\
\hline \multirow{3}{*}{ Group } & Control & $10.00 \pm 1.76$ & $18.40 \pm 2.11$ & & & \\
\hline & Nano-Silver & $17.00 \pm 2.66$ & $24.40 \pm 2.16$ & 0.014 & 0.166 & 0.178 \\
\hline & Biocidal & $22.20 \pm 4.37$ & $22.20 \pm 5.56$ & & & \\
\hline
\end{tabular}

The dead bees in groups in the laboratory trials are shown in the Table 3. 
Table 3: The dead bee numbers after the oral application

Tablo 3: Oral uygulama sonrası arı ölüm saylları

\begin{tabular}{lccccccccc}
\hline Group & & Group 1 & & Group 2 & \multicolumn{2}{c}{ Group 3 } \\
\hline Cage & $\mathbf{1}$ & $\mathbf{2}$ & $\mathbf{3}$ & $\mathbf{1}$ & $\mathbf{2}$ & $\mathbf{3}$ & $\mathbf{1}$ & $\mathbf{2}$ & $\mathbf{3}$ \\
\hline Total Bee Number & 10 & 10 & 10 & 10 & 10 & 10 & 10 & 10 & 10 \\
Dead Bee Number & 0 & 0 & 0 & 2 & 4 & 1 & 3 & 8 & 9 \\
\hline
\end{tabular}

There is a statistically significant difference between the groups in terms of the survival status of bees ( $\mathrm{P}$ $<0.001$ ) (Table 4). While the bees were alive in the control group, the percentage of bees died in the Nano silver group was $66.7 \%$. The proportion of bees dead in the Biocidal group is $23.3 \%$.

Table 4: The death rates in groups in in-vitro trials

Tablo 4: In vitro denemelerde grupların ölüm oranları

\begin{tabular}{lcccccc}
\hline & & Control & Nano-Silver & Biocidal & Total & P \\
\cline { 1 - 5 } The survival & Dead & $0(0.0 \%)^{\mathrm{a}}$ & $20(66.7 \%)^{\mathrm{b}}$ & $7(23.3 \%)^{\mathrm{c}}$ & $27(30.0 \%)$ & \\
status & Alive & $30(100.0 \%)^{\mathrm{a}}$ & $10(33.3 \%)^{\mathrm{b}}$ & $23(76.7 \%)^{\mathrm{c}}$ & $63(70.0 \%)$ & $<0.001$ \\
\cline { 1 - 5 } Total & & $30(100.0 \%)$ & $30(100.0 \%)$ & $30(100.0 \%)$ & $90(100.0 \%)$ & \\
\cline { 1 - 5 } & & &
\end{tabular}

$a, \overline{b, c}$ : The different letters in the lines indicate the statistical difference between the groups in the columns.

\section{Histomorphological Evaluations:}

The gastrointestinal system of bees which were randomly selected from each group was removed in a sterile way. The removed midgut and hindgut are shown in Figure 1. Afterwards, midgut samples were used for histomorphological evaluation. In histomorphological evaluation, it was determined that midgut epithelium integrity was significantly impaired, cell membranes were damaged especially in Nano-silver group when compared to the control group. In addition, it was observed that the peritrophic membrane also disappeared significantly, especially in the Nano-silver group. It was concluded that although the peritrophic membrane was still present in the Biocidal group, the membrane thickness was not sufficient. Beside that midgut epithelium showed a better morphology in terms of shape and integrity. Histomorphological changes in the midgut are shown in Figure 2.
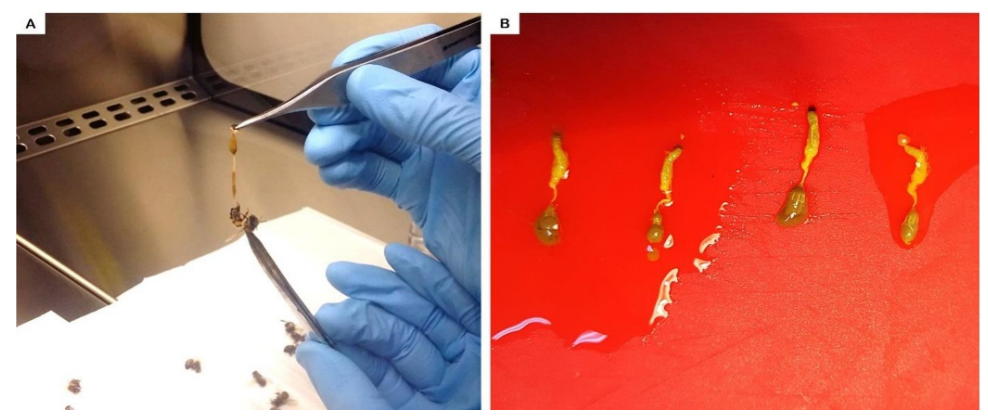

Figure 1: Removal of the digestive tract using sterile technique (A), Sections of the digestive tract (B).

Şekil 1: Sindirim sisteminin steril teknik kullanılarak çıkarllması (A), Sindirim sisteminin bölümleri (B). 

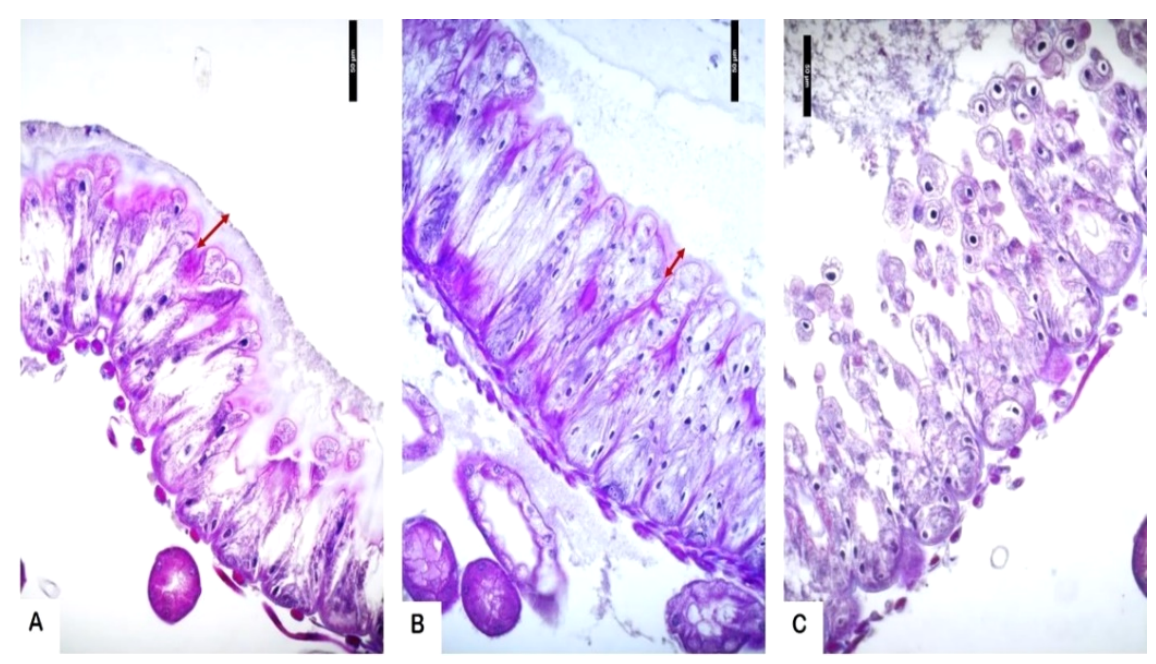

Figure 2: A. Control group. Peritrophic membrane (bi-directional arrow) B. Biocidal disinfectant group. Peritrophic membrane (bi-directional arrow) C. Nano-Silver group. Scale bars represent $50 \mu \mathrm{m}$.

Şekil 2: A. Kontrol grubu. Peritrofik membran (çift yönlü ok) B. Biyosidal dezenfektan grubu. Peritrofik membran (çift yönlü ok) C. Nano-Gümüş grubu. Bar50.

\section{Discussion and Conclusion}

Considering its richness of flora, climatic weather conditions, the honey bee genetic diversity, and its geographical location, despite being a major beekeeping country, Turkey has not reached the desired level in colony productivity. The biggest reason for that is the diseases seen in bees and the pests common in Turkey Rapid transportation in the world, trade of bees, bee products and beekeeping materials between countries and continents caused the spread of bee diseases to all countries in a short time. Unconscious and wrong fight practices cause economic losses and lead to the diseases to spread to healthy colonies (25). In the fight against bee diseases, unconscious longterm medication resulting from the wrong practices and overdosing should be considered as an important problem. As a result of the use of unlicensed drugs, bee disease factors and pests that have developed resistance against related active substances have occurred $(10,26,27)$. In addition, although drug use is prohibited in beekeeping for many years, illegal practices are still being carried out, which causes residual problems especially in bee products $(28,29,30)$.

Honey bee colonies are exposed to infection or infestation by various pests and diseases. It is important that beekeepers not only recognize the symptoms of such pests and diseases, but also know how to reduce their effects in colonies, beehives and the region. The key factor in preventing the spread of infection is good hygiene $(31,32,33)$. Before transmitted to the animal and infect it, the destruction of the pathogens causing the disease both contributes economically and reduces the use of veterinary medicinal products that will be applied in need. In addition, developing resistance of bee pathogens against drugs used in beekeeping can be prevented. There are many disinfectant materials used for cleaning beekeeping equipment (especially hives). However, the study investigating the effects of these chemicals on bees is very limited. Disinfectants used in beekeeping should be acceptable, without toxic effects on bees and not leave any residue in bee products.

In this study, on both field and laboratory conditions, the effects of biocidal and nano-silver-containing disinfectant preparates used in the field of beekeeping in our country were evaluated. According to the results of the study, both disinfectant preparations applied to the hives in the field conditions caused more bee deaths than the control group and the deaths were more common in the hive applied with disinfectant containing nano-silver. In in vitro trials, the nano-silver-containing preparation caused high mortality and serious damage to the midgut epithelium in histomorphological examinations. Besides, it was concluded that disinfectants used in the trials lead to malnutrition in the bees probably. Malnutrition is considered to be happened due to the negative effect of both products used in the 
study and their effect on the peritrophic membrane.

By many researchers, Ag-TiO2, ZnTiO2, TiO2 (21), ZnO (34), PVF + (Polivinil ferrocene) K2PdCl4 and Pt / $\mathrm{PVF}+(20), \mathrm{CdO}$ and metal nanoparticles. $\mathrm{PbO}(35,36)$ toxic effects on honey bees were investigated. Similar to the results of our study, it was determined that nanoparticles cause death in honey bees depending on the dose and time in all studies.

Extracts of parts of some plants such as root, aboveground parts or active substances obtained from these plants have long been used as antiviral, antibacterial (Paenibacillus larvae), fungicidal (Ascosphaera apis) and antiparasitic (against Varroa destructor) $(37,38,39)$. The fact that the existing medicines used in the treatment of diseases have started to lose their effects over time caused researchers and drug companies to search for new types of drugs against these pathogens. Nanoparticles have emerged recently due to their unique physical and chemical properties and high surface / volume ratio as new antimicrobial agents $(40,41)$. Among the different types of nanoparticles, it has found use in various biomedical applications, especially silver nanoparticles, bactericidal, fungicidal, antiviral and antiprotozoal $(42,43,44,45,46)$.

Application of disinfectants should be performed while no bees are present in the hives. Otherwise, this can cause oral consumption of disinfectants leading to higher death rates of bees. The emptied hives should be soaked with the disinfectants for a while. Thus, the negative effects of disinfectants on bees will be eliminated. If disinfectants will be used against bee pathogens, proper dosing should be made with in vitro and in vivo studies and their toxic effects on the bees should be examined as well. With the determining the toxic dose of the disinfectants used in hive cleaning, bee deaths resulted from excessive use of disinfectants and residue problem in the bee products can be prevented.

\section{Conflict of Interest}

The authors declared that there is no conflict of interest.

\section{Funding}

This study was not supported or not studied granting by any foundation. During this study, Sentezfarma company has a direct connection with the research subject and provides commercial product.

\section{Authors' Contributions}

Idea / concept: Sedat Sevin

Experiment design: Sedat Sevin, Gökhan Akdeniz, Fatih Yılmaz

Supervision / Consultancy: Ender Yarsan

Data collecting: Sedat Sevin, Ahmet Ceylan, Özge Özgenç, Gökhan Akdeniz, Fatih Yılmaz, Dilek Kabakçı

Data analysis and interpretation: Sedat Sevin, Ahmet Ceylan, Gökhan Akdeniz, Fatih Yılmaz, Dilek Kabakçı

Literature search: Sedat Sevin, Ahmet Ceylan, Özge Özgenç, Gökhan Akdeniz, Fatih Yılmaz, Dilek Kabakçı Writing the article: Sedat Sevin, Ahmet Ceylan, Gökhan Akdeniz

Critical review: Ender Yarsan

\section{Ethical Statement}

An ethical statement was received from the authors that the data, information and documents presented in this article were obtained within the framework of academic and ethical rules and that all information, documents, evaluations and results were presented in accordance with scientific ethics and moral rules.

\section{References}

1. Bilir EK, Sevin S, Tutun H, Alcigir ME (2018): Cytotoxic and antiproliferative effects of Rhododendron pontificum L. extract on rat glioma cell line (F98). Int J Pharm Sci Res, 9(5), 1000-1007.

2. Thakur M (2012): Bees as pollinators-Biodiversity and Conservation. IRJAS, 2(1), 1-7. 
3. Yalçın H, Ağaçsapan B, Çabuk A (2019): Geographical Information Systems and Identfying Proper Location of Beekeeping Location. Gs1 Journals Ser1e C: AIST, 1(2), 1-15.

4. Van der Sluijs JP, Vaage NS (2016): Pollinators and global food security: the need for holistic global stewardship. Food ethics, 1(1), 75-91.

5. Çevrimli MB (2018): Current situation, problems and solutions for beekeeping sector in turkey. Erciyes Üniv Vet Fak Derg, 15(1), 58-67.

6. Çağlıyan A (2015): Apiculture activities throughout the bitlis country. J Geography, (30), 1-25.

7. Alparslan ÖS, Demirbaş N (2019): Avrupa birliği ve türkiye'de bal üretim ve ticareti açısından coğrafi işaret uygulamalarının değerlendirilmesi. Yyu J Agr Sci, 29(3), 526-538.

8. Kence A (2006): Importance of Genetic diversity and its presevation of honey bee of Turkey. U Ar1 D-U Bee J, 6(1), 25-32.

9. Tutun H, Kahraman HA, Aluc Y, Avci T (2019): Investigation of some metals in honey samples from West Mediterranean region of Turkey. Vet Res Forum, 10(3), 181-186.

10. Uzundumlu A, Aksoy A, Ișı HB (2011): Current structure and basic problem in Beekeeping Operation; A case of Bingol. Atatürk Univ J of Agricultural Faculty, 42(1), 49-55.

11. Genersch E (2010): Honey bee pathology: Current threats to honey bees and beekeeping. Appl Microbiol Biotechnol, 87, 87-97.

12. Neumann P, Carreck NL (2010): Honey bee colony losses. J Apic Res, 49, 1-6.

13. Taric E, Glavinic U, Stevanovic J, Vejnovic B (2019): Occurrence of honey bee (Apis mellifera L.) pathogens in commercial and traditional hives. J Apic Res, 58(3), 433-443.

14. Arslanbaş E (2017): Treatment of diseases in organic beekeeping. Turkiye Klinikleri J Vet Sci Pharmacol ToxicolSpecial Topics, 3(1), 38-45.

15. Gürler B (2003): Up-to-date guide for selection and use of disinfection Congress Book of Sterilisation and Disinfection. Simad Publisher, Samsun, 159-168.

16. Titera D, Michal B, Dolinek J, Haklova M (2009): Hygiene in the apiary. Contract PL, 22568, 6th.

17. Kemp GK, Kross, RD (2000): U.S. Patent No. 6,096,350. Washington, DC: U.S. Patent and Trademark Office.

18. Yarsan E (2008): Disinfection methods of animal house and indoor space. Tarm Turk, 9,75-78.

19. Dağlığlu Y, Kabakcı D, Akdeniz G, Çelebi MS (2016): Determining the acute toxic effects of poly (vinylferrocenium) supported platinum nanoparticle (pt/pvf+nps) on Apis mellifera. MJST, 2(2), 1-8.

20. Dağlıŏlu Y, Kabakcı D, Akdeniz G (2015): Toxicity of nano and non-nano boron particles on Apis mellifera (honey bee). Res J Chem Environ Sci, 3, 6-13.

21. Özkan Y, Irende İ, Akdeniz G, Kabakçi D (2015): Evaluation of the comparative acute toxic effects of TiO2, $\mathrm{Ag}$-TiO2 and ZnOTiO2 composite nanoparticles on honeybee (Apis mellifera). J Int Environ Appl Sci, 10, $26-36$.

22. Güneş ME, Borum AE, Özakın C, Girişgin AO (2012): A new technic: efficacy of nano-silver coating of honey bee hives against some microorganisms. U Ar1 D-U Bee J, 12(1), 23-30.

23. EPPO (2010): PP 1/170 (4): Side-effects on honey bees. EPPO Bulletin, 40(3), 313-319.

24. Ceylan A, Özgenç Ö, Erhan F, Sevin S, Yarsan E (2019): Nosemosis' in (nosematosis) bal arısı (Apis mellifera) midesine etkileri üzerine histokimyasal gözlemler. Vet Hekim Der Derg, 91(2), 98-103.

25. Uygur ÖŞ and Girişgin O (2008): Honey bee diseases and mites. U Arı D-U Bee J, 8(4), 130-142.

26. Ayan A, Tutun H, Aldemir OS (2019): Control Methods against Varroa Mites. Int J Adv Stud, 11(2), 19-23.

27. Tutun H, Koç N, Kart A (2018) Plant essential oils used against some bee diseases. Turkish JAF Sci Tech y, 6(1), 34-45.

28. Al-Waili N, Salom K, Al-Ghamdi A, Ansari MJ (2012): Antibiotic, pesticide, and microbial contaminants of honey: human health hazards. Sci World J.

29. Sammataro D, Untalan P, Guerrero F, Finley J (2005): The resistance of varroa mites (Acari: Varroidae) to acaricides and the presence of esterase. Int $\mathrm{J}$ Acarol, 31(1), 67-74.

30. Korkmaz SD, Kuplulu O, Cil GI, Akyuz, E (2017): Detection of sulfonamide and tetracycline antibiotic residues in Turkish pine honey. Int J Food Prop, 20, 50-55.

31. Andersen EM (1980): Hive protection and bee disease eradication by heat sterilization. In: Proceedings of the XXVIIth International Congress of Apiculture, Athens (1979): (pp 329-334). Apimondia Publishing House.

32. Burnside CE (1931): Disinfection of american foulbrood combs by fumigation with formaldehyde -I. Bee World, 12(1), 3-7.

33. De Guzman ZM, Cervancia CR, Dimasuay KGB, Tolentino MM (2011): Radiation inactivation of Paenibacillus larvae and sterilization of American Foul Brood (AFB) infected hives using Co-60 gamma rays. Appl Radiat Isot, 69(10), 1374-1379. 
34. Milivojević T, Glavan G, Božič J, Sepčić K (2015): Neurotoxic potential of ingested ZnO nanomaterials on bees. Chemosphere, 120,547-554.

35. Naggar YA, Dabour K, Masry S, Sadek A (2018): Sublethal effects of chronic exposure to CdO or PbO nanoparticles or their binary mixture on the honey bee (Apis millefera L.). Environ Sci Pollut Res, 1-12.

36. Dabour K, Al Naggar, Y, Masry S, Naiem E (2019): Cellular alterations in midgut cells of honey bee workers (Apis millefera L.) exposed to sublethal concentrations of CdO or PbO nanoparticles or their binary mixture. Sci Total Environ, 651,1356-1367.

37. Chaimanee V, Thongtue U, Sornmai N, Songsri S (2017): Antimicrobial activity of plant extracts against the honeybee pathogens, Paenibacillus larvae and Ascosphaera apis and their topical toxicity to Apis mellifera adults. J Appl Microbiol, 123(5), 1160-1167.

38. Isidorov VA, Buczek K, Segiet A, Zambrowski G (2018): Activity of selected plant extracts against honey bee pathogen Paenibacillus larvae. Apidologie, 49(6), 687-704.

39. Damiani N, Fernández NJ, Porrini MP, Gende LB (2014): Laurel leaf extracts for honeybee pest and disease management: antimicrobial, microsporicidal, and acaricidal activity. Parasitol Res, 113(2), 701-709.

40. Ahluwalia V, Kumar J, Sisodia R, Shakil NA (2014): Green synthesis of silver nanoparticles by Trichoderma harzianum and their bio-efficacy evaluation against Staphylococcus aureus and Klebsiella pneumonia. Ind Crops Prod, 55, 202-206.

41. Guilger-Casagrande M, de Lima R (2019): Synthesis of silver nanoparticles mediated by fungi: a review. Front Bioeng Biotech, 7.

42. Fayaz AM, Ao Z, Girilal M, Chen L, Xiao X (2012): Inactivation of microbial infectiousness by silver nanoparticles-coated condom: a new approach to inhibit HIV-and HSV-transmitted infection. Int J Nanomedicine, 7, 5007.

43. Villeret B, Dieu A, Straube M, Solhonne B (2018): Silver nanoparticles impair retinoic acid-inducible gene Imediated mitochondrial antiviral immunity by blocking the autophagic flux in lung epithelial cells. ACS nano, 12(2), 1188-1202.

44. Khan SU, Anjum SI, Ansari MJ, Khan MHU (2018): Antimicrobial potentials of medicinal plant's extract and their derived silver nanoparticles: A focus on honey bee pathogen. Saudi J Biol Sci, 26(7), 1815-1834.

45. Sadeghi B, Gholamhoseinpoor F (2015): A study on the stability and green synthesis of silver nanoparticles using Ziziphora tenuior (Zt) extract at room temperature. Spectrochim Acta A, 134, 310-315.

46. Baker C, Pradhan A, Pakstis L, Pochan DJ (2005): Synthesis and antibacterial properties of silver nanoparticles. J Nanosc1 Nanotechno, 5(2), 244-249. 